\title{
O. Stanisław Józef Płatek OSPPE, Wybrane zagadnienia z historii i duchowości paulinów Paulinianum, Wydawnictwo Zakonu Paulinów, Jasna Góra - Częstochowa 2009, 362 s.
}

Duchowość życia zakonnego ma bogatą tradycję i uznane miejsce w chrześcijaństwie, choć jednocześnie prezentuje sobą wieloraką różnorodność. To powołanie m.in. drogi życia konsekrowanego o szczególnym profilu, życia zakonnego. Przybierała ona na przestrzeni wieków wielorakie formy i znamiona. Co więcej, ciągle jest otwarta na nowe propozycje i drogi. Zawsze jednak podstawowym centrum było podejmowanie rad ewangelicznych, tj. ubóstwa, czystości i posłuszeństwa. Na tej drodze, choć w różnych formach szczegółowych, wiele pokoleń osiągnęło szczególną bliskość z Bogiem i ludźmi.

W to bogactwo eklezjalne twórczo wpisuje się także starożytna wspólnota paulińska, która w 2008 roku dziękowała za 700 lat zatwierdzenia przez Stolicę Apostolską. Jej refleksja historyczna oraz dynamika jest zadatkiem pozytywnych perspektyw ku przyszłości, choć zawsze żywo odniesionych do przeszłości. Zawsze bowiem, całe dzieje zbawienia, a w tym i posługi paulińskiej, mają konkretne odniesie do realiów chrześcijańskiego życia.

Oto Zakon Paulinów udostępnił interesujące opracowanie poświęcone historii i duchowości całej wspólnoty, w całym jej bogactwie i specyfice. Jest to już 218 tom wydany przez Paulinianum, cenne wydawnictwo wielorakich tekstów bibliograficznych oraz źródłowych. Wydaje się że rozprawa ta jest stosunkowo jasnym i zarazem odpowiedzialnym opracowaniem, które jednocześnie budzi duże nadzieje ku przyszłości wiary. Nie można jednak jednocześnie pominąć faktu, iż to ostatecznie i to w stopniu zasadniczym księga Pisma Świętego Nowego Testamentu jest fundamentem całej duchowości wszystkich dróg życia konsekrowanego.

Do całości pracy wstęp zredagował o. Izydora Matuszewskiego, obecny przełożony generalny wspólnoty paulińskiej (s. 5). Następnie rozprawa podzielona została na dziewięć części - rozdziałów o dość zróżnicowanej objętości. Te zaś z kolei podzielone zostały na dalsze szczegółowe i bardzo precyzyjne podgrupy tematyczne. Taka systematyka jest ciekawą pomocą w lekturze całej książki.

Początki zakonu św. Pawła Pierwszego Pustelnika to tytuł pierwszego rozdziału (s. 7-53). Kolejny blok koncentruje się wokół tematu: Organizacja zakonu: urząd general a zakonu, tworzenie się prowincji w wieku XIV-XVI (s. 55-72). Dalej ukazano informacje $\mathrm{z}$ okresu odnowy duchowej zakonu po Soborze Trydenckim (s. 73-120).Z kolei wskazano na paulinów z okresu rozwoju zakonu - prowincji 
polskiej XVII-XVIII (s. 121-150). Idąc dalej podjęto temat: Studium filozoficznoteologiczne wakonie $i$ w prowincji polskiej (s. 151-168).

Zaprezentowano także działalność apostolską (s. 169-201). W to wpisują się również charakterystyczne cechy duchowości paulinów (s. 203-229).

Podejmowane próby kasaty zakonu to tematyka kolejnego rozdziału (s. 231-257). Z kolei w bloku Odrodzenie się zakonu ukazano w kolejności Argentynę, Australię, Belgię, Białoruś, Chorwację, Czechy, Francję, Kamerun, Łotwę, Niemcy, Polskę, Republikę Południowej Afryki, Słowację, Stany Zjednoczone Ameryki Północnej, Szwecję, Ukrainę, Węgry, Wielką Brytanie i Włochy (s. 259-356). To aktualne kraje posługi ewangelizacyjnej paulinów, którzy rozproszyli się w wielu krajach oraz niemal na wszystkie kontynenty.

Były przełożony generalny zakonu ukazuje ważne elementy historii i duchowości paulinów, a więc swojej rodziny zakonnej. Okazuje się bowiem na przestrzeni dziejów, iż jest to niezwykle bogate spełnianie się ewangelizacji, w charyzmacie tej wspólnoty zakonnej, inspirowanej św. Pawłem, pierwszym pustelnikiem. Doświadczenie naukowe, dydaktyczne oraz badawcze ojca generała wydało interesujący owoc, który jest twórczym wskazaniem do dalszej refleksji wokół historii i duchowości paulińskiej.

Aktualny generał prezentując książkę stwierdza: „Ta cenna monografia sytuuje w aktualnym kontekście charakterystyczne rysy życia wewnętrznego paulinów; celnie uwydatnia ponad siedmiowiekowy proces ewolucji duchowości Zakonu paulinów - począwszy od pierwszych reguł węgierskich przez kolejne redakcje Konstytucji zakonnych, aż po odnowę wskazaną przez Sobór Watykański II" (s. 5). Oto ważne nakreślenie idei, które mają przystawać do współczesności.

Węgierskie pochodzenie zakonu w niczym nie przysłania jego uniwersalności i powszechności oraz otwartości na posługę w Kościele powszechnym, czego dowodem jest choćby niezwykle dynamiczna posługa w Polsce, i to nie tylko na Jasnej Górze w Częstochowie. Dokonany w rozdziale 9. przegląd ukazuje to jeszcze dobitniej, zwłaszcza w sferze administracyjnej. Jest to ważne wskazanie na zewnętrzne struktury, ale jednocześnie o wiele ważniejszym jest duch. Należy jednak zdecydowanie jeszcze wyraźniej nawiązywać do tego źródła i nurtu teologii oraz duchowości.

Słusznie zauważa autor przedmowy prezentowanej książki: „To monograficzne opracowanie, wsparte także na doświadczeniach Jego posługi jako generała Zakonu paulinów, jest wielkim i przydatnym dobrem dla przyszłości paulinów" (s. 5). Nie ulega wątpliwości, że pilnie potrzebnym jest bardziej pogłębiona refleksja, która łączy elementy historii i duchowości. Szkoda, że tylko w stopniu dość minimalnym wybrzmiały szersze konteksty paulińskich informacji, których jest jednak stosunkowo wiele. Wydaje się bowiem, że byłoby to w praktyce waż- 
nym elementem pomocniczym dla interpretacji wielu szczegółowych kwestii odnoszących się do zakonu.

Szkoda, że w publikacji nie zamieszczono wstępu czy słowa wprowadzającego. Podobnie brak zakończenia czy podsumowania. Byłyby to ważne elementy, w których byłaby możliwość przedstawienia uwag wprowadzających czy podsumowujących. Takich elementów zawsze się oczekuje, także od strony metodologicznej. Ze względu na charakter międzynarodowy zakonu oczekiwanym jest choćby krótkie streszczenie w języku angielskim czy innym.

Szkoda, że w książce zasadniczo zabrakło przypisów, a jeśli to występują one dość sporadycznie. Ten zabieg zawsze jest ważnym elementem formalnym, a jednocześnie bardzo cenionym, również współcześnie. Wyraźny jest brak bibliografii, tak odnośnie do źródeł jak i literatury przedmiotu oraz pomocniczej. W pracy o charakterze historycznym pomocnym byłby indeks nazwisk, a może i miejscowości.

Dobrze, że w całości obrazu paulinów wybrzmiewa ówczesna teologia moralna. To tak ogólne zasady jak i ich praktyczna aplikacja w konkretnych realiach życia pielgrzymów. Zwłaszcza poprzez Sanktuarium Jasnogórskie byli oni bardzo związani ze spowiednictwem, przecież to było ich szerokie zaangażowanie. Stąd zapewne w tym środowisku wyrosły opracowania teologiczne $\mathrm{z}$ tego zakresu, choćby np. Grzegorza Tereckiego czy Andrzeja Gołdanowskiego.

Dobrze, że między stronami 64-65, 128-129, 192-193, 224-225, 288-289 zamieszczono dość obszerną, a zarazem i interesującą dokumentację fotograficzną. To jest ważny element całej narracji i przybliża ikonograficznie wiele postaci oraz wydarzeń związanych zwłaszcza z Jasną Górą, tak w przeszłości jak i nieodległej teraźniejszości.

To rozproszenie klasztorów paulinów na tak wielu kontynentach i w tak wielu krajach wydaje bardzo różnorodne owoce. Stanowią one znamiona obecności w bardzo zróżnicowanych miejscach, gdzie podejmują także bardzo różne posługi. Szczególnie warto tutaj zwrócić uwagę m.in. na Amerykańską Częstochowie - Doylestown. Stała się ona ważnym miejscem manifestacji wiary dla Polonii amerykańskiej.

Trzeba przyznać, że dobór materiałów i konstrukcja pracy jest dość przypadkowa, co $\mathrm{w}$ znacznym stopniu utrudnia systematykę studium zakreślonych w tytule książki szczegółowych problemów. Można wręcz odnieść wrażenie, że poszczególne rozdziały stanowią zwarte i systematyczne opracowania czy bloki tematyczne. Zatem jawią się w całej książce podstawowe pytania o historię i duchowość. Dobrze, że autor wskazuje, iż niektóre teksty, które były wcześniej publikowane wyszły spod pióra innych autorów (s. 131).

Z kart prezentowanej książki tchnie duże umiłowanie zakonu, co zapewne jest ważnym znamieniem dla całej polskiej wspólnoty oraz jej wielorakich dzieł dla Boga, ludzi i świata. Można odnieść wrażenie, że nie wyrasta to tylko 
z przynależności autora, którą sam deklaruje, i to w różnych formach. Próbuje on bowiem wyjść poza osobiste uwarunkowania, i pełniej rozeznać miejsce tej wspólnoty zakonnej w Kościele powszechnym oraz poszczególnych Kościołach lokalnych.

Bp Andrzej F. Dziuba 